\title{
Solar Green Roofs: A Unified Outlook Twenty Years On
} \begin{abstract}
last decade
Abstract: Solar green roofs, namely rooftops functionalized with properly selected living vegetation and photovoltaic modules, achieve an ideal symbiotic relationship in which promotion of biodiversity and onsite renewable energy production are both enhanced whereas the roof provides a wide range of environmental, health, aesthetic and economic benefits. This study provides a unified outlook of this eminent sustainable technology at the dawn of its uptake across the world, especially in polluted urban areas.
\end{abstract}

Rosaria Ciriminna, ${ }^{[\mathrm{a}]}$ Francesco Meneguzzo, ${ }^{*[\mathrm{~b}]}$ Mario Pecoraino, ${ }^{[\mathrm{c}]}$ and Mario Pagliaro*[a]

This study is dedicated to Raffaella Galiano, chemist and entrepreneur, for all she did to avance clean technology in Italy in the course of the

\section{Introduction}

Reminding that less than $5 \%$ of buildings globally were functionalized with PV modules in early $2017,,^{[1]}$ we recently provided arguments and recommendations to undertake a global effort using today's largely affordable solar photovoltaic (PV) technology to functionalize the existing building stock. ${ }^{[2]}$

This evolution, for decades impeded by the high cost and by the poor aesthetics of PV technology, is now entirely feasible thanks to dramatic progress occurred in the solar PV industry which has led in the course of the last decade to a truly global solar boom. ${ }^{[3]}$

Almost concomitantly, the green roof technology evolved from the roof-garden concept to the extensive green roof comprised of a light system of layers having a thin soil depth and droughtresistant vegetation on top, especially suitable for large flat roofs in urban areas. ${ }^{[4]}$

In general, green roofs add a wide range of environmental, health, economic and aesthetic benefits such as reduced energy consumption for heating, habitat restoration and increased urban biodiversity, rainwater retention, reduced noise and air pollution, and heat island effect mitigation. ${ }^{[5]}$

Only in terms of real carbon sequestration potential, data from two studies on vegetated roofs to quantify the carbon accumulation potential of green roofs (in both plant biomass and soil substrate) point to $187.5 \mathrm{~g} \mathrm{C} \cdot \mathrm{m}^{-2}$ year ${ }^{-1}$ of carbon removal rate, equivalent if all Detroit's roofs were covered with such a

[a] Dr. M. Pagliaro, Dr. R. Ciriminna

Istituto per lo Studio dei Materiali Nanostrutturati, CNR

via U. La Malfa 153

90146 Palermo (Italy)

E-mail: mario.pagliaro@cnr.it

[b] Dr. F. Meneguzzo

Istituto di Biometeorologia, CNR

via Madonna del Piano 10

50019 Sesto Fiorentino (Italy)

E-mail: francesco.meneguzzo@cnr.it

[c] M. Pecoraino

via C. Giacquinto 14

90135 Palermo (Italy) roof to sequester almost 28,000 tonnes of carbon every year from air. ${ }^{[6]}$

Aptly called "biosolar roofs" ${ }^{\text {"[7] }}$ to underline the symbiotic role in promoting biodiversity and onsite renewable energy production in the urban built environment, green solar roofs are rooftops functionalized with PV modules and properly selected vegetation.

Biodiversity is enhanced, in comparison to conventional green roofs, because the $\mathrm{PV}$ modules on the green roof provide on their back an excellent microhabitat for insects and birds, while shadow behind the panels results in better and more diverse living and vegetation conditions due to the substrate retaining moisture. ${ }^{[8]}$

Production of electricity is enhanced because the green roof lowers the roof's temperature compared with conventional roofs. $^{[9]}$

Despite all these benefits, as of January 2019 a search using the query "green roofs" on a research online database returned 176,000 hits, ${ }^{[10]}$ the number of solar green roofs across the world reported in late 2018 was "rather rare", ${ }^{[11]}$ and "nearly nonexistent" in 2016. ${ }^{[12]}$

Three year later, the price of $\mathrm{PV}$ modules has broken the $\$ 0.30 / \mathrm{W}$ threshold with average module prices priced $\$ 0.278$ per watt for standard polycrystalline silicon modules by mid 2018 (\$0.337/W for polycrystalline PERC modules. and \$0.363/W for monocrystalline PERC modules). ${ }^{[13]}$

Similarly, the efficiency and durability of PV modules, with the widespread adoption of the rear passivation layers technology (PERC) ${ }^{[14]}$ has reached such high level to make the adoption of PV energy on all world's building within the next two decades a reasonable forecast and expectation.

This study offers a unified outlook of this eminent sustainable technology focusing on practical aspects that so far have prevented its widespread uptake across the world, especially in polluted urban areas.

The outcomes of the study will aid to expand and improve knowledge of green solar roofs, which is often been poor even among practitioners of rooftop solar energy practitioners and energy managers. 


\section{Technology, ecological and energy aspects}

Today's extensive green roof technology employs a multilayer system, with a waterproof membrane at the bottom, a drainage layer, a soil growth substrate (with a filter layer separating it from the drainage layer), and the critically important vegetation layer comprised of plant species able to withstand drought conditions and to survive under minimal nutrient conditions. ${ }^{[15]}$

The water content of a green roof, with its wet soil and drainage layer, is always significant making mandatory the insertion of a root-resistant waterproof membrane for any quality (long-lasting and zero-defect) solar green roof. "Aa single drop of water leakage in roof" has written Vijayaraghavan, "should be considered as a failure of green roof". ${ }^{[15]}$

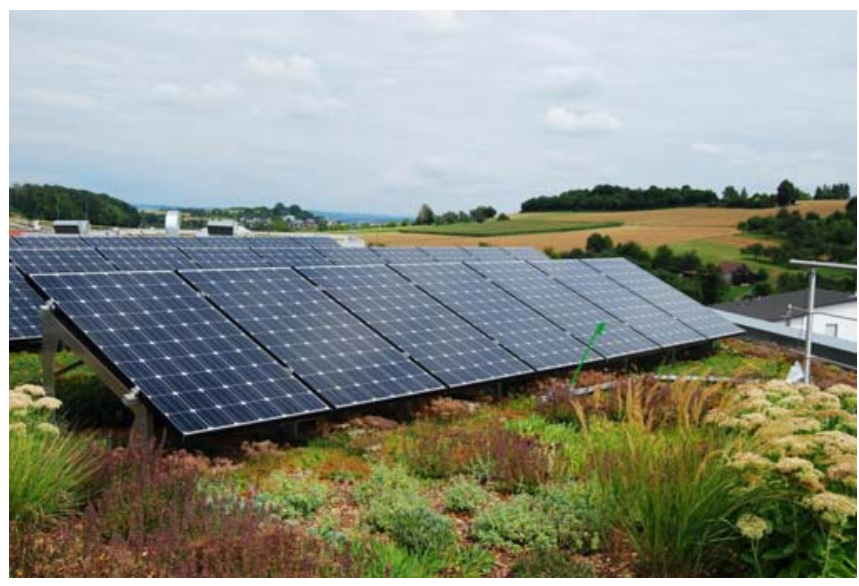

Figure 1. The green roof provides a superimposed load. There is no roof penetration thanks to the superimposed load principle. [Photo courtesy of ZinCo].

Compared to a conventional extensive green roof, a solar green roof includes an extra layer ("solar base") where to lay the frames on which the PV modules are eventually installed. The whole installation is straightforward and takes place in six steps. $^{[9]}$

Using aptly developed PV module mounting frames, there is no need for roof penetration since the green roof provides the superimposed load required to protect the system against wind uplift (Figure 1). ${ }^{[9]}$

Although Sedum species were the dominant plant chosen for extensive green roofs for over two decades, succulent plants have lately emerged as suitable plants especially in hot climates since these species can withstand longer periods of drought, and are more likely to resume growth soon after water is made available. ${ }^{[16]}$

Testing a properly installed set of PV modules (and not single modules) over a green roof comprising eight plant species including Opuntia fragilis (Figure 2), a team of scholars in Colorado found that the shade cast by the PV module string during the morning hours establishes gradients in substrate moisture, solar irradiance, and temperatures, with the substrate surface acting as a thermal sink relative to exposed roof surfaces. ${ }^{[17]}$

Temperature variations below the PV modules, for example, were markedly lower amounting to $3.92^{\circ} \mathrm{C}$ and $6.36^{\circ} \mathrm{C}$, respectively, for substrate surface beneath the modules in sheltered areas and in exposed areas. ${ }^{[17]}$
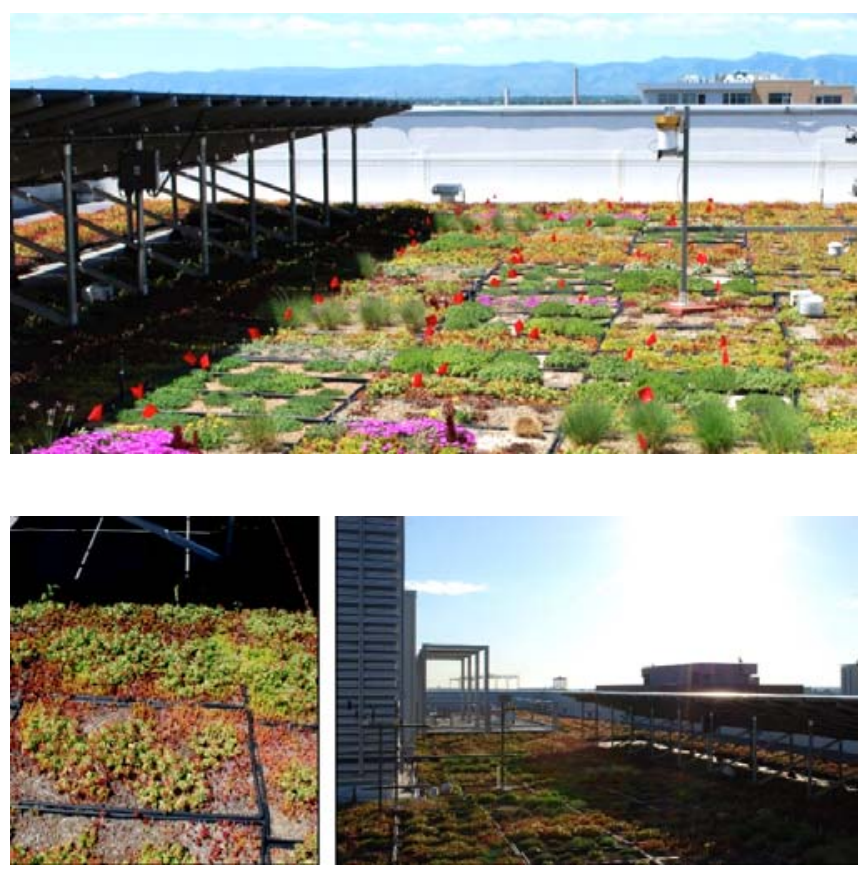

Figure 2. Effects of protection from the PV array on the green roof where vegetation appears to have greater coverage (left) in areas shaded from direct sunlight for a portion of each day (right). [Reproduced from Ref.17, with kind permission]

The green roof areas beneath and close to the PV array remained fully vegetated, whereas coverage in the exposed areas was patchy which is, the scholars noted, a typical condition in moisture-deprived plants exposed to high levels of direct solar irradiance (bottom of Figure 2). ${ }^{[17]}$

As mentioned above, the biodiversity potential habitat for wildlife in a solar green roof is enhanced in comparison to a green roof, and can be further enhanced using competences from horticulturalists and conservation scholars. ${ }^{[8]}$

For instance, since 1999 the green roof the Hall 1 of Messehalle Basel (top of Figure 3, in Switzerland) with its $7 \mathrm{~cm}$ of volcanic substrate planted with low growing Sedum species, flowering herbs and forbs includes a large photovoltaic array deployed over $1,900 \mathrm{~m}^{2}$ of green roof which produces $215,000 \mathrm{kWh} /$ year.

In 2008 Brenneisen, a conservation scholar, added organic matter and woody debris to the roof thereby enhancing its biodiversity functions (Figure 3 ). ${ }^{[18]}$ 

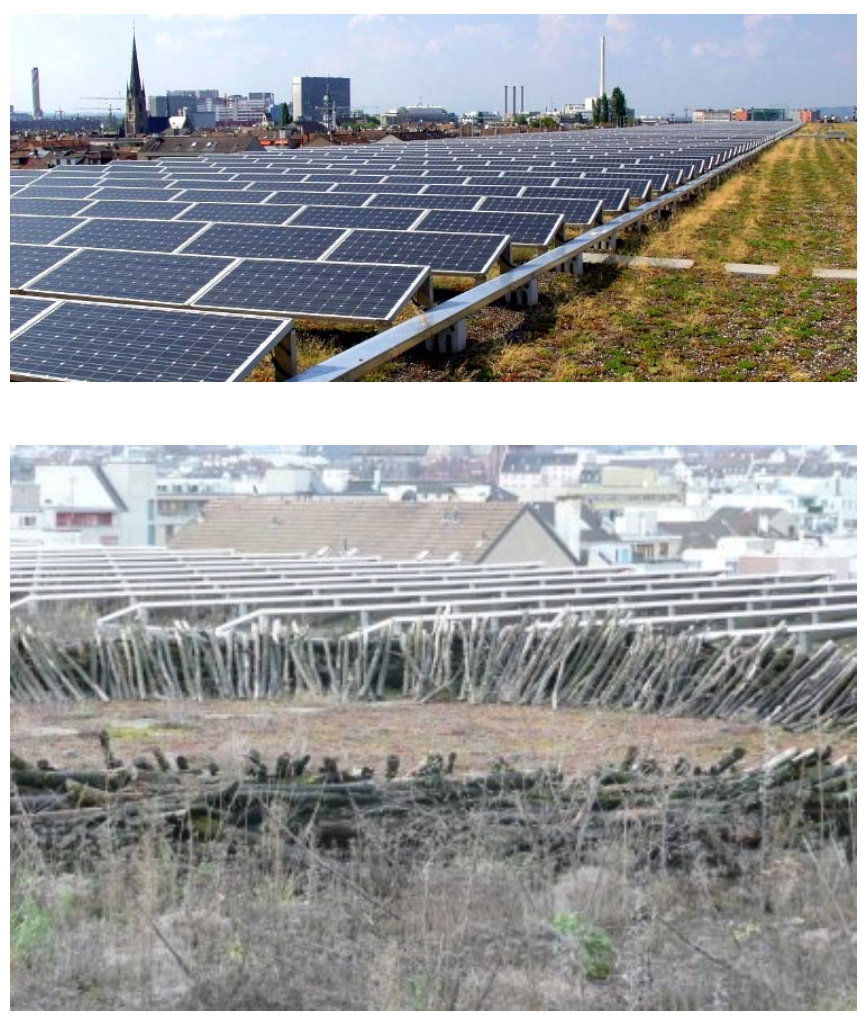

Figure 3. The solar green roof completed in 1999 on the Hall 1 of Messehalle Basel (top), and after addition of organic matter and woody debris in 2008 (bottom). [Reproduced from Ref.17, with kind permission]

The biosolar roof system in the subsequent years worked so well that in late 2013 a new PV array comprising 4,517 PV modules in monocrystalline silicon for an overall $1189.1 \mathrm{~kW}$ peak power due to produce around 1,080,000 kWh of clean electricity every year was installed with east-west orientation on the green roof of the new Messe Basel hall complex (Figure 4). ${ }^{[19]}$

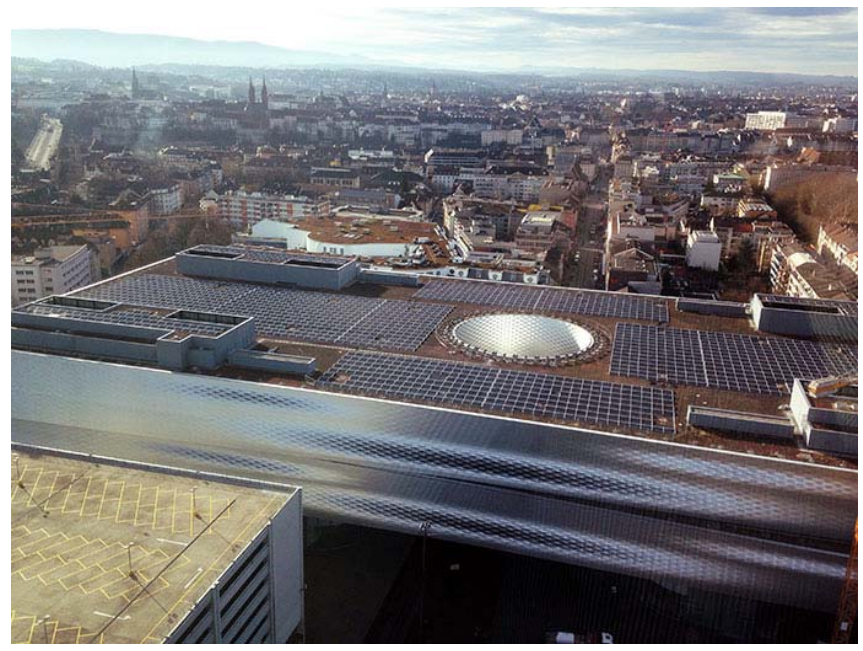

Figure 4. The $1189.1 \mathrm{~kW}$ solar green roof on main exhibition hall of the new Messe Basel. [Photo courtesy of Tritec Project Engineering].
Another option, besides conventional south-facing or east-west orientation of tilt PV modules, is to mount the modules vertically, especially when using new generation bifacial modules (i.e. modules with solar cells on both module sides).

This was again demonstrated by scholars in Switzerland installing a $9.09 \mathrm{~kW}$ PV array of custom made bifacial PV modules with 20 solar cells (to reduce the wind load and to improve the general appearance) on the rooftop of a building of Zurich University of Applied Sciences in Winterthur. ${ }^{[12]}$

The rooftop was partitioned into three parts: a regular green roof substrate with normal green-leaved plants, a gravel roof and a recycled green roof substrate combined with white gravel and silver-leaved plants (Figure 5, top).
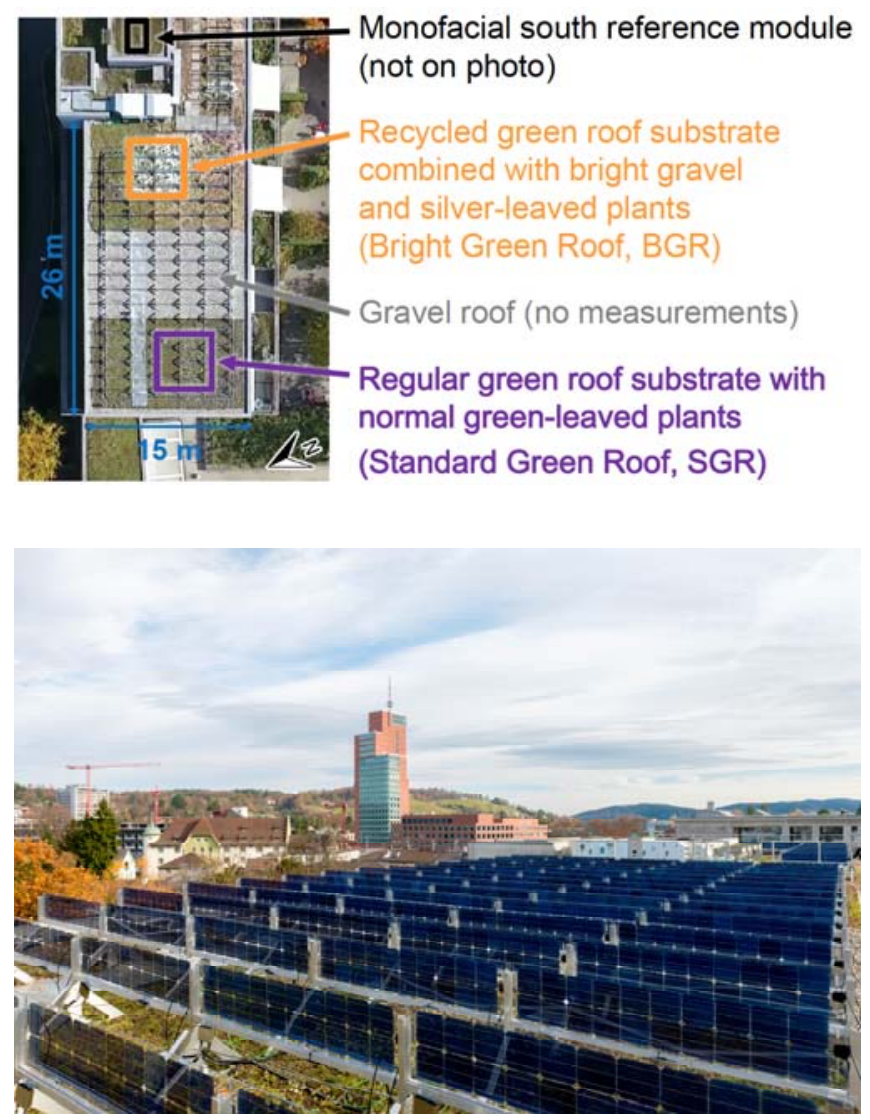

Figure 5. Aerial (top) and later (bottom) view of the $9,09 \mathrm{~kW}$ photovoltaic array on the rooftop of on the rooftop of a building of Zurich University of Applied Sciences in Winterthur. [Photo courtesy of T. Baumann and Zurich University of Applied Sciences].

In one year of continuous monitoring (between August 11, 2017 and August 10,2018) the PV array over the bright green roof comprising bright substrate and silver-leaved plants achieved a specific yield of $942 \mathrm{kWh} / \mathrm{kWp}$, almost identical (-1.4\%) compared to that measured for a south-facing monofacial PV module $\left(25^{\circ}\right.$ azimuth and $16^{\circ}$ tilt $)$ affording $1000 \mathrm{kWh} / \mathrm{kWp}^{[12]}$ 
The use of plants with good reflective properties, which are also well suited to the ambient conditions on flat roofs, resulted in a clean electricity yield increase of $17 \%$ compared to a standard green roof planting having a measured albedo (0.09) less than half of the albedo measured for the bright green roof $(0.21){ }^{[12]}$

Solar green roofs retain most of the benefits of conventional green roofs, including enhanced thermal insulation, the ability to lower urban air temperatures and mitigate the urban heat island effect (reducing the ambient air temperature by $4.2{ }^{\circ} \mathrm{C}$ in Singapore's tropical climate), ${ }^{[20]}$ while providing a more aesthetically pleasing urban or extra-urban landscape.

As expected, though, compared to conventional green roofs, green roofs with integrated PV modules are less effective in reducing stormwater runoff and peak flow.

This has been lately demonstrated by scholars in Canada who reported that during small and medium rainfalls a portion of rainwater is intercepted by the PV panel surface and concentrated into a narrow strip of the green roof along the panel dripline which creates localized saturated conditions within the substrate while the substrate directly beneath the PV modules remains relatively dry. ${ }^{[21]}$

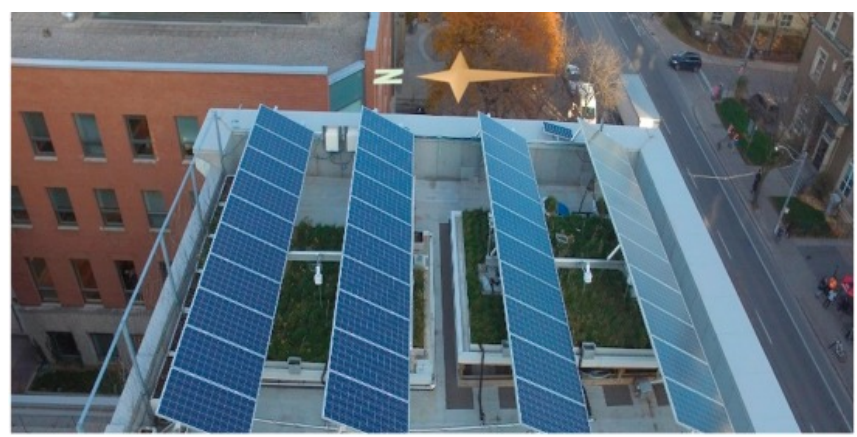

(a)

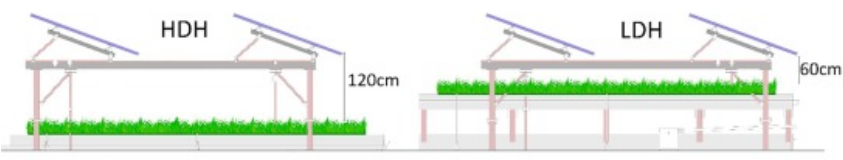

(b)

Figure 6. Two rows of PV panels mounted to racking structures above each green roof used for testing the water retention capacity on the fifth-story roof of a University of Toronto building located on the downtown St. George campus. The vertical distances between the PV panels and the GR surface are $0.6 \mathrm{~m}$ and $1.2 \mathrm{~m}$ for the south and north test modules, respectively. [Reproduced from Ref.21, with kind permission].

In detail, for rainfalls with small rainfall depth of $10 \mathrm{~mm}$ or less, rainwater retention of at least $90 \%$ was measured for the conventional green roof, whereas $61 \%$ and $75 \%$ rainwater retention values were recorded for the solar green roof with the $\mathrm{PV}$ modules featuring a vertical separation of $0.6 \mathrm{~m}(\mathrm{LDH})$ or 1.2 $\mathrm{m}(\mathrm{HDH}$, Figure 6), respectively.
The solar green roofs produced discharge with rainfalls in excess of $3 \mathrm{~mm}$, whereas in the conventional green roof discharge rarely occurred from events with less than $11 \mathrm{~mm}$ of rainfall (Figure 6). ${ }^{[21]}$

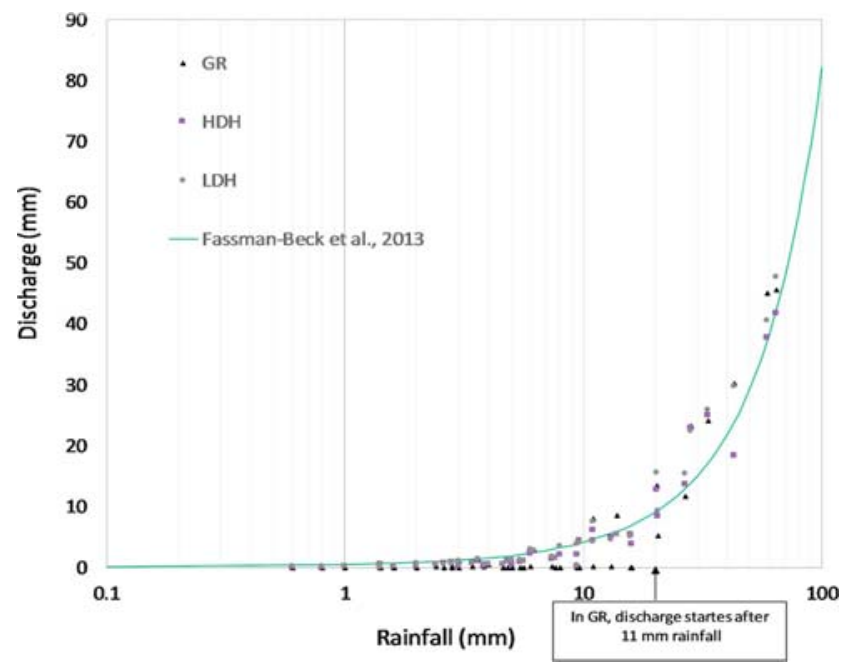

Figure 7. Discharge versus rainfall for solar (HDH and LDH) and conventional (GR) green roofs. LDH and $\mathrm{HDH}$ stand for photovoltaic green roof with modules featuring a vertical separation of $0.6 \mathrm{~m}$ or $1.2 \mathrm{~m}$, respectively. [Reproduced from Ref.21, with kind permission].

In case of large rainfalls, the difference between the conventional green roof and the solar green roof in terms of rainwater retention was minimal.

In principle, the combination of green roofs with $\mathrm{PV}$ modules should result in higher production of clean electricity due to the cooling effect of the vegetation especially during summer's hottest days when the surface temperature of a green roof rarely exceeds $30-35{ }^{\circ} \mathrm{C}$, when the temperature of a conventional flat rooftop in concrete or bitumen can easily exceed $80^{\circ} \mathrm{C}$.

Scholars based in Israel, however, recently reported no differences in module temperature and electricity production after testing for two years single PV modules installed on concrete with a bitumen membrane and on a green roof (Figure 8). ${ }^{[22]}$

The team ascribed this finding to the strong winds common in the area which effectively cooled the module on conventional roof, indeed found frequently cooler than modules on green roof, as well as to limited evapotranspiration from vegetation when the modules were warmest, namely in summer months featuring poor or completely absent rainfall.

In a Mediterranean climate, concluded the team, it would be appropriate to irrigate the green roof with PV panels to enhance the cooling effect due to evapotranspiration and thus electricity production. $^{[22]}$ 

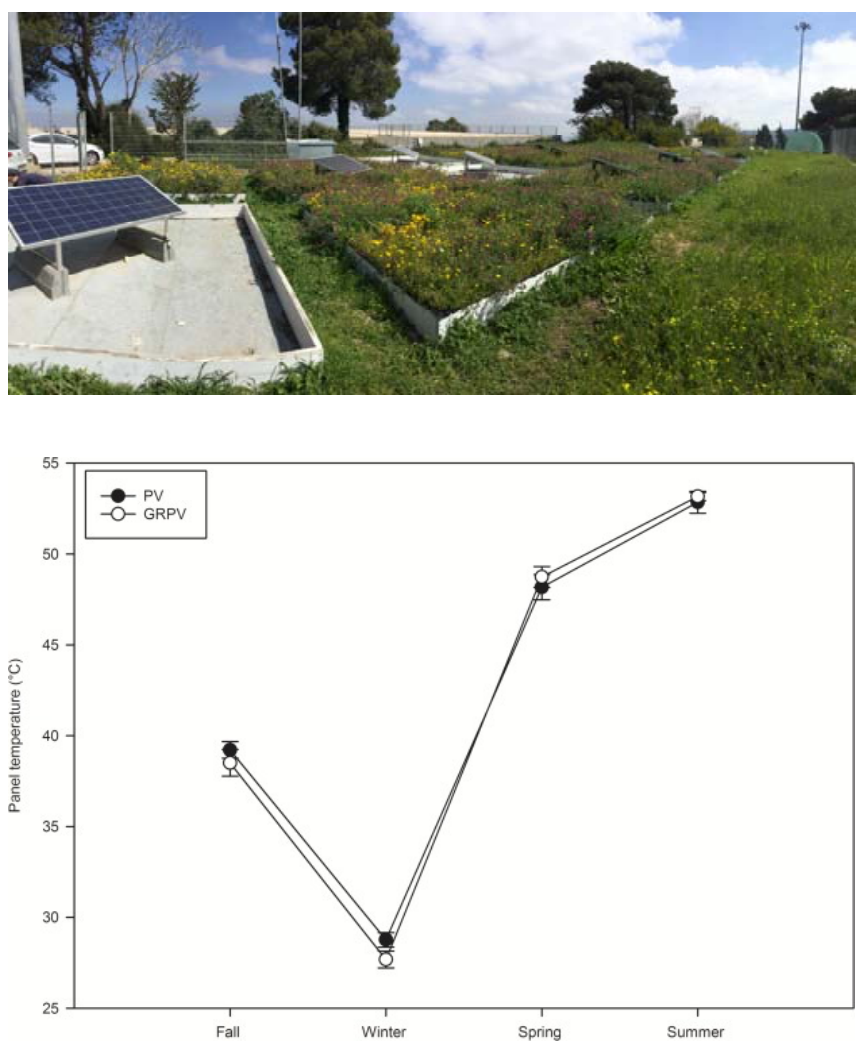

Figure 8. The PV modules on conventional and on green roof tested in 2016 and in 2017 at the University of Haifa, and the average of maximum daily temperature of photovoltaic panel in each season, in conventional roof (PV) and green roof (GRPV). [Reproduced from Ref.22, with kind permission].

Similar findings were reported by scholars in Singapore after comparing the temperature for a PV module on green and concrete roofs. ${ }^{[23]}$ Again, no differences in temperature were observed due to wind that, under the PV module on the green roof was obstructed thereby reducing its cooling effect.

The above findings were due to high wind speed throughout the year and poor rainfall in warm months, as indirectly shown by the outcomes of similar measurements carried out in a less windy region of Germany again using single PV modules placed nearby on conventional and onto green rooftop (Figure 9).

This time the difference in the measured values of the average daily temperature beneath the modules over the bitumen waterproofing membrane and the module on the green roof amounted to about $8{ }^{\circ} \mathrm{C}$ throughout the year. ${ }^{[9]}$

Subsequent measurements currently lasting since over three years invariably point to the same significant difference, confirming the cooling effect of the green roof.
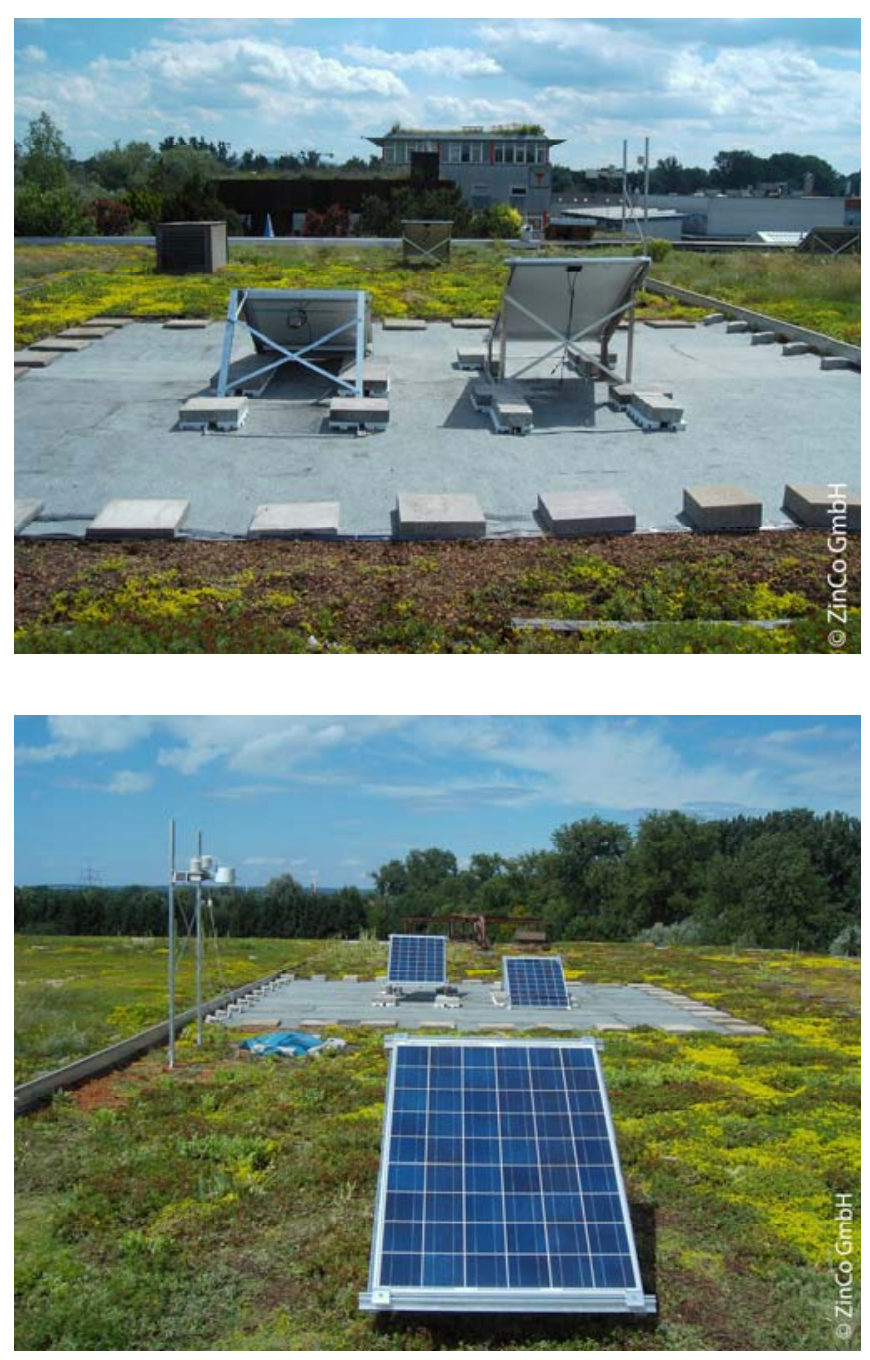

Figure 9. The PV modules tested during one solar year installed on bituminous membrane and on a green roof. [Photo courtesy of ZinCo].

Numerous other studies have shown a positive cooling effect of green roofs on the temperature of PV modules, and thus on energy production. Suffice it to cite here a year-long experimental study comparing the energy output of a $4.23 \mathrm{kWp}$ PV array installed over the roof of an educational building at the University of Kansas. ${ }^{[24]}$

In detail, nine PV modules in polycrystalline silicon, each with a $\mathrm{PV}$ temperature coefficient of power of $-0.0045 \mathrm{~W} /{ }^{\circ} \mathrm{C}$, were placed over a green roof in Sedum needing minimal amount of solar radiation and irrigation, and nine over a black roof bitumen membrane (Figure 10). 


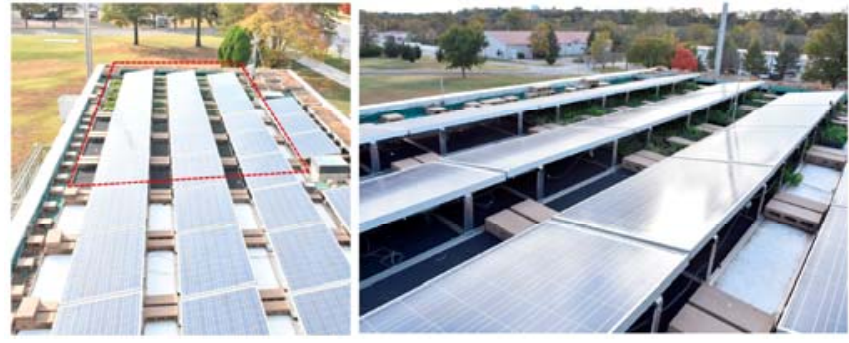

Figure 10. The PV modules tested during one solar year installed on bituminous membrane and on a green roof. The tilt angle for all the modules was fixed at $10^{\circ}$ facing south. [Reproduced from Ref.24, with kind permission].

Table 1. Monthly energy outuput and difference for the PV arrays installed over the green and bitumen membrane (EP-black) roof at the University of Kansas' Center for Design Research. [Reproduced from Ref.24, with kind permission].

\begin{tabular}{|c|c|c|c|c|}
\hline Month & $E_{\text {green }}(\mathrm{kWh})$ & $E_{\text {black }}(k W h)$ & $\begin{array}{l}\text { Difference } \\
(\mathrm{kWh})\end{array}$ & $\begin{array}{l}\text { Difference } \\
(\%)\end{array}$ \\
\hline Jan & 48.18 & 47.67 & 0.51 & 1.1 \\
\hline Feb & 102.86 & 102.47 & 0.39 & 0.4 \\
\hline Mar & 84.36 & 83.93 & 0.42 & 0.5 \\
\hline Apr & 141.82 & 141.86 & -0.04 & 0.0 \\
\hline May & 141.59 & 139.77 & 1.82 & 1.3 \\
\hline Jun & 254.52 & 239.79 & 5.73 & 2.4 \\
\hline Jul & 198.87 & 194.87 & 3.99 & 2.0 \\
\hline Aug & 165.85 & 163.13 & 2.72 & 1.7 \\
\hline Sept & 131.14 & 130.53 & 0.61 & 0.5 \\
\hline Oct & 94.28 & 92.86 & 1.41 & 1.5 \\
\hline Nov & 48.56 & 47.65 & 0.91 & 1.9 \\
\hline Dec & 36.32 & 35.36 & 0.96 & 2.7 \\
\hline TOTAL & 1439.34 & 1419.90 & 19.43 & 1.4 \\
\hline
\end{tabular}

The energy production of each individual solar module was measured with microinverters installed under each PV panel and the underside module surface, and ambient air temperatures with sensors which also returned the relative humidity.

After one solar year, the energy production of the solar green roof for the entire year was $1.4 \%$ higher than for the PV system over the conventional rooftop.
Correlated with temperature via the temperature coefficient of power, the differences in energy production between the two arrays were higher and significant during the hot days of the year, namely during June and July when the greatest variations in energy productions were recorded and when the energy production of PV systems achieved its highest levels (Table 1). ${ }^{[24]}$

The plot of the hours of the year in which the underside surface temperature for the modules on the bitumen roof was higher than the underside surface temperature of the PV modules on the green roof (Figure 11) shows that the average hourly underside surface temperature difference was about $3^{\circ} \mathrm{C}$, while the maximum underside surface temperature was approximately $6{ }^{\circ} \mathrm{C}$.

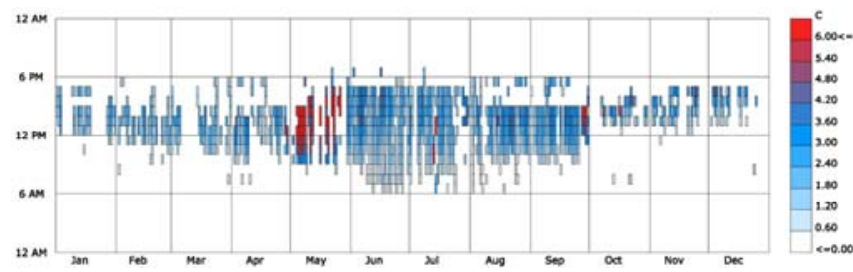

Figure 11. Hourly underside surface temperature differences of UST-Green vs. UST-Black. [Reproduced from Ref.1, with kind permission]

The highest differences were recorded during the peak temperature of the day suggesting that such differences will be even higher in warmer regions of the world, with more days of ambient air temperatures above $25^{\circ} \mathrm{C}$, such as in many African and Indian regions as well as in Middle East countries, and especially in urban areas where average temperatures are much higher than in extraurban areas.

\section{Solar cities, urban habitats}

The solar city concept, namely the use of the urban built environment to generate electricity via building-integration of PV modules, is not an utopian "scenario" for environmentalists but a realistic option whose significance derives from finding that more than $60 \%$ of a typical city daylight electricity need and over $30 \%$ of its all-hours demand can originate from such distributed energy generation approach. ${ }^{[25]}$

Referring to Rome and to the need to preserve the architectural integrity and historic value of old buildings and cultural heritage, we have lately identified the technology solutions, and the policy and educational initiatives to effectively achieve such global uptake of decentralized solar energy systems in the built environment within the next decade (2018-2027).$^{[1]}$

Green solar roofs are particularly necessary in large cities to combat air pollution, and for restoring biodiversity in urban areas.

In general, the fuel combustion in the internal combustion engine (ICE) of hundreds of thousands or even million vehicles systematically pollutes the air of cities across the world, 
threatening the health and wellbeing of people living or visiting said highly polluted cities. ${ }^{[26]}$

As Shenzhen has lately shown the world replacing the whole diesel bus and nearly all (95\%) of its taxi fleets with 16,359 battery electric buses and more than 19,000 battery electric taxis, air pollution from ICE vehicles will be ultimately resolved by electric vehicles. ${ }^{[27]}$

The contribution from green solar roofs in this evolution towards sustainable cities includes the concomitant generation of clean electricity and oxygen-rich clean air there where it is most needed, while restoring biodiversity.

As put it by Brenneisen writing in 2006 , when green roofs were still limited exclusive to some regions and not yet distributed as today:

«As a potential tool for preserving and restoring biodiversity in urban areas, green roofs need to be seen less from the perspective of ornamental gardening and energy conservation and more from a regional perspective of landscape and ecological planning. The functional and technical approach taken by most green roof developers and creators today can be enhanced by the spatial approach taken by conservation science practitioners». ${ }^{[28]}$

Large flat rooftops plentiful in cities are ideally suited for the installation of solar green roofs as they allow to minimize the cost of installation, and to maximize both the electricity generation, the development of vegetation and the promotion of biodiversity.

Besides the aforementioned Basel's Messe examples, this was clearly shown by London's $2500 \mathrm{~m}^{2}$ green solar roof installed on the rooftop of a new building completed in July 2011 (Figure 12), on the occasion of the 2012 Olympic Games.

The outcomes of a study carried out in 2013 monitoring the biodiversity of the roof were clear: ${ }^{[8]} 92$ plant species recorded on the roof representing a floristically diverse example of an extensive green roof, with the PV modules acting as refugia for plants during periods of drought; higher proportion of faunistically interesting invertebrate species in comparison to other green roofs in the same city; regular sightings of black redstart and linnet birds showing how the green solar roof acts also as a valuable foraging resource for rare (and protected) and common bird species.

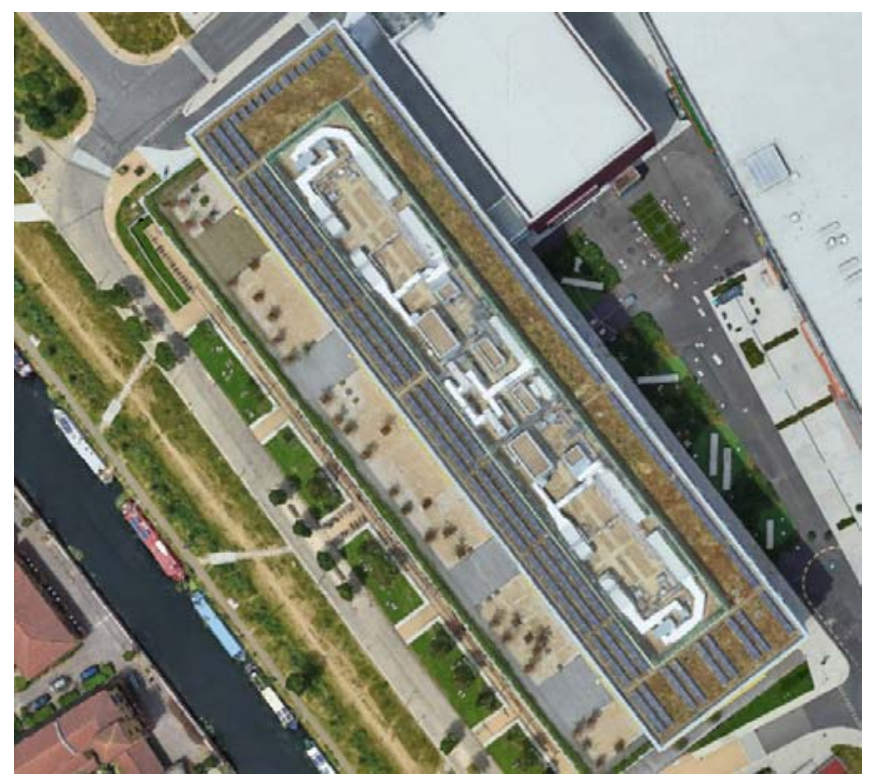

Figure 12. The four-storey London Olympics International Broadcast Centre hosts a $2,500 \mathrm{~m}^{2}$ green solar roof whose habitat attempts to mimic the open habitat of the Thames river corridor. [Photographs from Google Earth].

It is instructive, at this stage, to review what the Basel's municipality (where around $23 \%$ of the city's flat roof area, around $700,000 \mathrm{~m}^{2}$, was green roof as early as of 2006) ${ }^{[29]}$ requires for green roofs made mandatory for all new buildings with a flat roof: the growing medium, at least $10 \mathrm{~cm}$ deep, should be native regional soils; the growing medium should be; and vegetation should be a mix of native plant species, characteristic to Basel. ${ }^{[29]}$

As mentioned above, practical progress concerning green roofs has been so rapid that large cities such as Toronto have already devised Guidelines for Biodiverse Green Roofs ${ }^{[30]}$ aimed at designing true pollinator habitats on green roofs, well beyond the first Sedum-based extensive roofs. The concept of careful planning of green roofs with diverse vegetation as an essential requirement to increase their value as habitats, ${ }^{[31]}$ is now widely shared among green roof practitioners.

What remain less known are the main energy and ecological implications of solar green roofs among renewable energy practitioners and energy managers, as traditionally the construction of a solar PV rooftop array has not required specialist horticultural or ecological expertise.

Indeed scholars in Switzerland lately ascribed the poor uptake of the solar green roofs to the lack of proper education with several cases in which the selected vegetation was wrong, and positioning and orientation of the PV modules was not correct. ${ }^{[7]}$ 


\section{Recommendations}

Expanding the knowledge and skills of energy managers and practitioners of solar energy with green solar roof science and technology ideally takes place at new solar energy research and educational institutes whose foundation is critically important to shape the professionals needed to guide the transition to renewable energy and the bioeconomy. ${ }^{[32]}$

Starting from the energy aspects of green roofs, ${ }^{[33]}$ said energy professionals will learn how to effectively manage the installation of green solar roofs able to afford large amounts of clean electricity while taking into consideration how each newly developed green roof fits into the broader goal of biodiversity conservation by assessing the potential ecological costs ("the shadows, as well as benefits", to say it with Holt). ${ }^{[34]}$

As in the case of today's highly effective courses on solar energy for energy managers, ${ }^{[35]}$ we recommend proper balance between theory and hands-on, practical education. We recommend to pay at least one visit to a well designed green solar roof, and o host at least two presentations offered by leading practitioners of the green roof industry involving suggestions on how to create a skilled labour force able to install and maintain a green solar roof.

Dealing with advanced education aimed at energy managers, and not at undergraduate students, the economic and practical aspects of utilizing solar green roofs energy in urban areas will be given priority, consistent with the managerial role of today's energy managers. ${ }^{[36]}$

When electricity is generated on the roof and consumed in the building, the distributed generation situation is achieved, and average losses of 7 to $10 \%$ from transmission and distribution lines is avoided. We remind that such losses increase exponentially as power lines become heavily loaded, so that avoiding a small amount of electricity demand in the highest peak hours can reduce line losses by as much as 20 percent. ${ }^{[37]}$

Driven by the urgency of oil, population and wealth conflicting dynamics first identified by a single model in 2016, ${ }^{[38]}$ China is facing the otherwise uneasy economic and geopolitical consequences of reliance on imported fossil fuels (coal, natural gas and oil) by deploying at fast rate an huge amount of renewable power generators fed by water, wind and sunlight.

In brief, total power generation in China has risen from around 1400 TWh in the late 1990s to 6400 TWh in 2017, when power generation from renewable energy sources reached $1600 \mathrm{TWh}$ moderating the growing fossil fuel gap by $20 \%$, down from putative 9600 TWh to $8000 \mathrm{TWh}^{[39]}$

In the words of Mathews and Huang: "Had China been dependent on fossil fuel imports to a putative level of $9600 \mathrm{TWh}$, this would have condemned the country to extreme dependence on geopolitical hotspots for its fuel imports". ${ }^{[3]}$ Indeed, the fossil fuel gap between consumption and production in China in 2017 amounted to 684 million tonnes oil equivalent, which in terms of electric power generation translates into a gap of approximately 8000 TWh in 2017. ${ }^{[39]}$

Four root causes were lately identified by Chinese scholars to limit green roof penetration in China's cities: increased maintenance, design and construction costs, poor arrangement of the use of green roofs, and lack of incentives towards developers. ${ }^{[40]}$

The team recommended the deployment of financial incentives and new mandatory regulation together with better dissemination "of the benefits, particularly lifecycle cost benefit, among building stakeholders". ${ }^{40]}$

No better dissemination argument, we add, than focusing on the immediate and prolonged economic benefits derived by the installation of a solar green roof whose electricity production is enhanced in comparison to a conventional rooftop PV array substantially paying by itself the extra cost incurred to design, install and maintain the green roof, especially today that a PV array will last at least 30 consecutive years with today's state of the art modules (most of which are produced in China) losing less than $0.4 \%$ of their original productivity every year. ${ }^{[41]}$

\section{Conclusions}

The solar green roof technology is an advanced form to generate clean electricity and provide numerous ecological services in the new distributed generation energy framework which offers tangible and prolonged benefits in both developed and developing countries.

Both residential and non-residential buildings are perfectly suited to host green solar roofs, creating at the same time a significant number of new jobs, as rooftop PV installations support almost 3 times as many jobs than ground-mounted installations (only in the 28 countries of the European Union rooftop solar could provide 150,000 jobs by 2021). ${ }^{[42]}$

It will be enough to clear ambiguity related to net metering, exempting rooftop solar electricity producers from undue financial burdens such as overly high administrative fees to unleash the huge potential of rooftop solar PV, including solar green roofs, across the world.

In India after the government announced the Jawaharlal Nehru National Solar Mission in 2010, rooftop installations went from zero to 2,538 MW as of March 2018, growing annually at a compound annual rate of 117 per cent between 2013-14 and $2017-18 .^{[43]}$

The world's second most populous country targets to install $40,000 \mathrm{MW}$ of rooftop solar power capacity by 2022 , and even if so far only $3 \mathrm{GW}$ were installed, the opportunities for solar green roofs are truly significant, especially in the country's largest cities where air pollution is a serious public health issue. 
Similarly, Turkey targets $10,000 \mathrm{MW}$ of rooftop PV (4,000 MW for residential rooftop PV applications and 6,000 MW for industrial and commercials systems) by 2026 .

Numerous other countries have similar ambitious targets. With the price of solar modules having reached historic low levels and global production capacity due to reach $124 \mathrm{GW}$ by 2019 (compared to $104 \mathrm{GW}$ in 2017), ${ }^{[44]}$ it may not be surprising to learn that the global rooftop solar market is expected to achieve compound annual growth rate above $9 \%$ until $2022 .{ }^{[45]}$

New educational, research and communication efforts including the present study will be instrumental in turning a significant fraction of the new solar rooftops into solar green roofs.

\section{Acknowledgements}

Thanks to Thomas Baumann, ZHAW Zurich University of Applied Sciences, School of Engineering; Bracha Y. Schindler, Institute of Evolution and Department of Evolutionary and Environmental Biology, University of Haifa; and Vincent de Haas ZinCo $\mathrm{GmbH}$, for kindly sharing some of the photographs reproduced in this study.

Keywords: solar energy $\bullet$ solar green roof $\bullet$ energy transition • biosolar roof $\bullet$ green roof $\bullet$ air pollution

[1] S. Castellanos, D. A. Sunter, D. M. Kammen, Rooftop solar photovoltaic potential in cities: how scalable are assessment approaches?, Environ. Res. Lett. 2017, 12, 125005.

[2] R. Ciriminna, M. Pecoraino, F. Meneguzzo, M. Pagliaro, Integrating Solar Energy in Rome's Built Environment: A Perspective for Distributed Generation on Global Scale, Adv. Sust. Syst. 2018, 2, 1800022.

[3] F. Meneguzzo, R. Ciriminna, L. Albanese, M. Pagliaro, The Great Solar Boom: A Global Perspective into the Far Reaching Impact of an Unexpected Energy Revolution, Energy Sci. Eng. 2015, 3, 499-509.

[4] E. Oberndorfer, J. Lundholm, B. Bass, R. R. Coffman, H. Doshi, N. Dunnett, S. Gaffin, M. Köhler, K. K. Y. Liu, B. Rowe, Green Roofs as Urban Ecosystems: Ecological Structures, Functions, and Services, BioScience 2007, 57, 823-833.

[5] K. L. Getter, D. Bradley Rowe, The role of extensive green roofs in sustainable development, HortScience 2006, 41, 1276-1285.

[6] K. L. Getter, D. Bradley Rowe, G. Philip Robertson, B. M. Cregg, J. A. Andresen, Carbon Sequestration Potential of Extensive Green Roofs, Environ. Sci. Technol. 2009, 43, 19, 7564-7570.

[7] C. Catalano, N. Baumann, Biosolar Roofs: A Symbiosis between Biodiverse Green Roofs and Renewable Energy, City Green - Verdant Cities 2017, 15, 42-48.

[8] C. Nash, J. Clough, D. Gedge, R. Lindsay, D. Newport, M. A. Ciupala S. Connop, Initial insights on the biodiversity potential of biosolar roofs: a London Olympic Park green roof case study, Isr. J. Ecol. Evol. 2016, 62, 74-87.

[9] ZinCo, Solar Energy and Green Roofs, Nuertingen (Germany): 2017. See at the URL: www.zinco-arabia.com/sites/default/files/201704/Solar_Energy_and_Green_Roofs.pdf

[10] Search conducted using Google Scholar, excluding patent and citations, January 24, 2019.

[11] T. Baumann, D. Schär, F. Carigiet, A. Dreisiebner, F. Baumgartner, Performance analysis of green roof systems, $32^{\text {nd }}$ European Photovoltaic Solar Energy Conference and Exhibition, Munich, June 2016.
[12] T. Baumann, F. Carigiet, R. Knecht, M. Klenk, A. Dreisiebner, H Nussbaumer, F. Baumgartner, Performance analysis of vertically mounted bifacial PV modules on green roof system, $35^{\text {th }}$ European Photovoltaic Solar Energy Conference and Exhibition, Brussels, 24 to 27 September 2018.

[13] C. Roselund, Global PV module prices collapse, pv magazine, 21 June 2018. See at theURL: www.pv-magazine.com/2018/06/21/global-pvmodule-prices-collapse/

[14] The production of monocrystalline PERC solar cells is due to exceed 60 GW production levels during 2019 to become the industry's dominant technology. See at: F. Colville, Mono PERC cell production to lead solar industry in 2019, pvtech, 18 January 2019. See at theURL: www.pv-tech.org/editors-blog/mono-perc-cell-production-to-lead-solarindustry-in-2019

[15] K. Vijayaraghavan, Green roofs: A critical review on the role of components, benefits, limitations and trends, Renew. Sust. Energ. Rev. 2016, 57, 740-752.

[16] J. M. Bousselot, J. E. Klett, R. Koski, Extensive green roofs in Colorado: Plant species performance, growing media modifications, and species response to growing media dry down, HortScience 2011, 46, 518-522.

[17] J. M. Bousselot, T. Slabe, J. Klett, R. Koski, Photovoltaic array influences the growth of green roof plants, J. Living Architect. 2017, 4, 9-18.

[18] J. Labbe, "Some green \& gritty rooftops in Basel, Switzerland, Stephan Brenneisen and Basel's Biodiverse green roofs", 7-9 December 2009. See at the URL: https://jim-labbe.travellerspoint.com/16/

[19] Tritec, Construction start of solar power plant at the new Basel Trade Fair Centre construction, tritec-energy.com, 12 December 2013.

[20] N.H. Wong, Y. Chen, C.L. Ong, A. Sia, Investigation of thermal benefits of rooftop garden in the tropical environment, Build. Environ. 2003, 38, 261-270.

[21] A. Jahanfar, J. Drake, B. Sleep, L. Margolis, Evaluating the shading effect of photovoltaic panels on green roof discharge reduction and plant growth, J. Hydrol. 2019, 568, 919-928.

[22] Y. Schindler, L. Blaustein, R. Lotan, H. Shalom, G. J. Kadas, M. Seifan, Green roof and photovoltaic panel integration: Effects on plant and arthropod diversity and electricity production, J. Environ. Manage. 2018, 225, 288-299.

[23] S. Gupta, P. Anand, S. Kakkar, P. Sagar, A. Dubey, Effect of evapotranspiration on performance improvement of photovoltaic - green roof integrated system, Int. J. Renew. Energy 2017, 12, 63-75.

[24] M. J. Alshayeb, J. D. Chang, Variations of PV Panel Performance Installed over a Vegetated Roof and a Conventional Black Roof, Energies 2018, 11(5), 1110.

[25] J. Byrne, J. Taminiau, J. Seo, J. Lee, S. Shin, Are solar cities feasible? A review of current research, International Journal of Urban Sciences 2017, 21, 239-256.

[26] B. Hoffmann, Air Pollution in Cities: Urban and Transport Planning Determinants and Health in Cities, In: Integrating Human Health into Urban and Transport Planning, M. Nieuwenhuijsen, H. Khreis (Ed.s) Springer, Cham: 2019; pp. 425-441.

[27] M. Pagliaro, F. Meneguzzo, The driving power of the electron, J. Phys. Energy 2019, 1: 011001.

[28] S. Brenneisen, Space for Urban Wildlife: Designing Green Roofs as Habitats in Switzerland, Urban Habitats 2006, 4, 27-36.

[29] A. Kazmierczak, J. Carter, Adaptation to climate change using green and blue infrastructure. A database of case studies, University of Manchester, Manchester: 2010; pp.105-109. See at the URL: https://orca.cf.ac.uk/64906/1/Database_Final_no_hyperlinks.pdf

[30] City of Toronto, Guidelines for Biodiverse Green Roofs, Toronto: 2013. See at the URL: https://web.toronto.ca/wpcontent/uploads/2017/08/8d24-City-of-Toronto-Guidelines-forBiodiverse-Green-Roofs.pdf

[31] J. S. Maclvor, O. Starry, S. Brenneisen, N. Baumann, G. Grant, G. Kadas, M. Köhler, J. T. Lundholm, Introduction: "Looking up" to Green 
Roofs to Understand Urban Biodiversity - A Decade On, Urban Naturalist 2018, 1, 2-8.

[32] M. Pagliaro, F. Meneguzzo, Que faire? A Bioeconomy and Solar Energy Institute at Italy's Research Council in the Context of the Global Transition to the Solar Economy, Chem. Eur. J. 2017, 23, 15276-15282.

[33] O. Saadatian, K. Sopian, E. Salleh, C. H. Lim, S. Riffat, E. Saadatian, A. Toudeshki, M. Y. Sulaiman, A review of energy aspects of green roofs, Renew. Sust. Energ. Rev. 2013, 23, 740-752.

[34] R. D. Holt, Green roofs may cast shadows, Isr. J. Ecol. Evol. 2016, 62, 15-22.

[35] R. Ciriminna, F. Meneguzzo, M. Pecoraino, M. Pagliaro, Rethinking Solar Energy Education on the Dawn of the Solar Economy, Renew. Sust. Energy Rev. 2016, 63, 13-18.

[36] R. Ciriminna, M. Pecoraino, F. Meneguzzo, M. Pagliaro, Reshaping the education of energy managers, Energy Res. Soc. Sci. 2016, 21, 44-48.

[37] National Association of Clean Air Agencies, Implementing EPA's Clean Power Plan: A Menu of Options, Washington, D.C.: 2015; Reduce Losses in the Transmission and Distribution System, 10-1.

[38] F. Meneguzzo, R. Ciriminna, L. Albanese, M. Pagliaro, The energypopulation conundrum and its possible solution, arXiv 2016 1610.07298 [physics.soc-ph].

[39] J. Mathews, X. Huang, China's green energy revolution has saved the country from catastrophic dependence on fossil fuel imports, energypost.eu, 21 March 2018.

[40] X. Chen, C. Shuai, Z. Chen, Y. Zhang, What are the root causes hindering the implementation of green roofs in urban China? Sci. Total Environ. 2019, 654, 742-750.

[41] In three year outdoor aging test carried out by China Building Material Test \& Certification Group. the average degradation of state $f$ the art photovoltaic modules in monocrystalline Si was $0.38 \%$ in the first year, $0.32 \%$ in the second year, and $0.36 \%$ in the third year. See at: LONG Solar, Stellar Results by LONGi Solar's Monocrystalline Modules in CTC's Outdoor Tests. Three-Year Degradation Rate Only 1.06\%, longisolar.com, Hainan: 23 November 2018.

[42] Ernst \& Young, Solar PV Jobs \& Value Added in Europe. London: 2017.

[43] "With 4 years to go, just $6 \%$ of solar rooftop target installed", economictimes.indiatimes.com, 8 August 2018.

[44] Technavio, Global Rooftop Solar Market 2018-2022, London: 2018.

[45] According to independent PV manufacturing analyst Corrine Lin cit. In: B. Beetz, 14 PV trends for 2019, pv-magazine.com. 31 December 2018. 


\section{Solar Green Roofs: A Unified Outlook Twenty Years On}

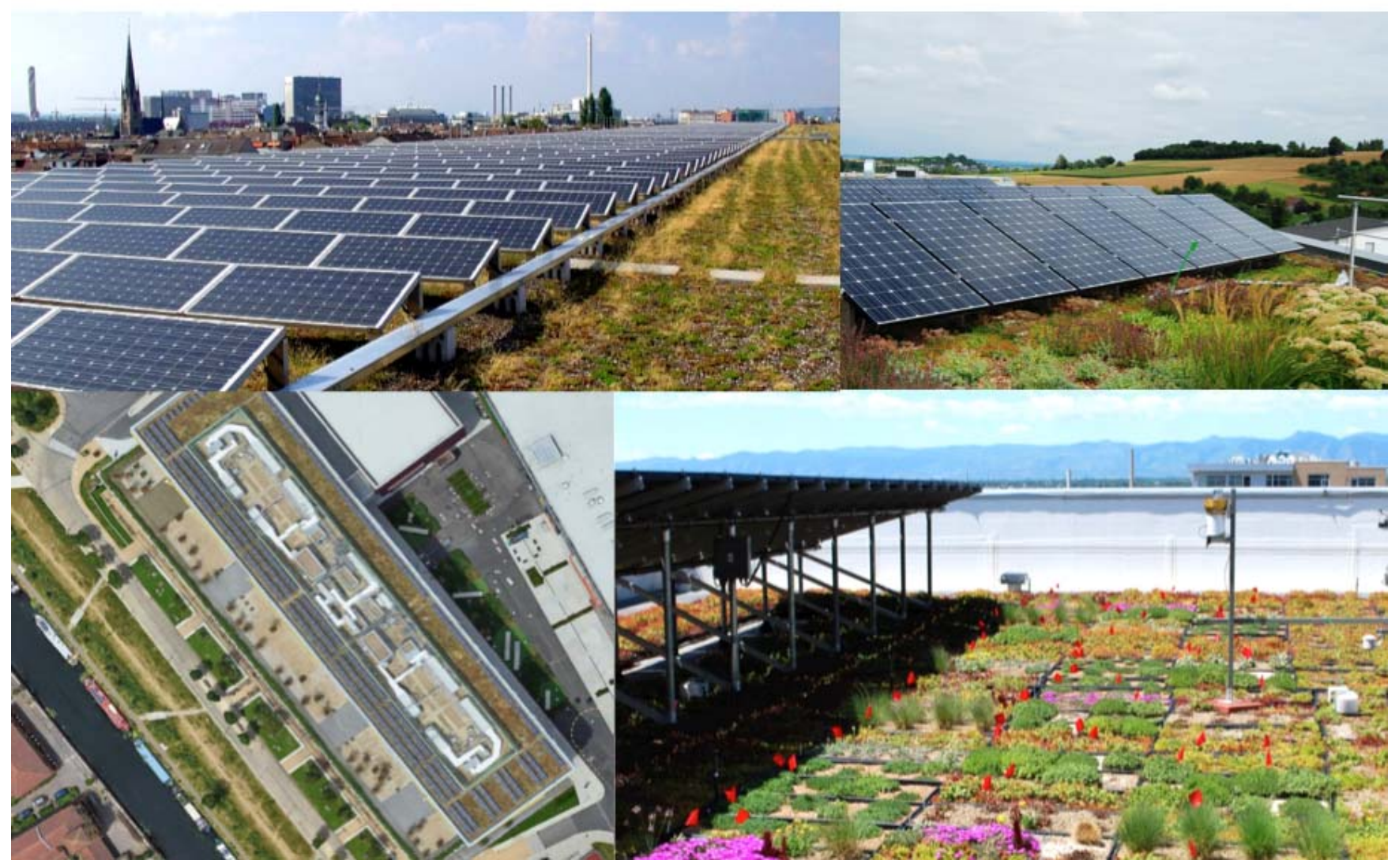

